\title{
TOURISM IN PHIPUN DISTRICT: FROM DARK TO DAWN
}

\author{
Chamaiporn Buddharat \\ Nakhon Si Thammarat Rajabhat University \\ Kanaporn Kaewkamjan \\ Nakhon Si Thammarat Rajabhat University \\ Viyada Promchitta \\ Nakhon Si Thammarat Rajabhat University \\ Wichien Phanon \\ Nakhon Si Thammarat Rajabhat University \\ Kanyarat Sirirat \\ Nakhon Si Thammarat Rajabhat University \\ Yusop Boonsuk* \\ Prince of Songkla University \\ Mano Sipaoraya \\ Office of Phipun Administration
}

\begin{abstract}
This paper presents two tragic stories which provided great impacts, not only on the villagers' way of life in Phipun District, Thailand, but also on Thai people and logging business worldwide. The samples were 24 participants including villagers, resort and restaurant owners, and entrepreneurs. Participatory Action Research was used as a paradigm. Interview and participant observation were utilized for data collection and qualitative content analysis was applied for data analysis. The findings revealed that the invasion of communist party to the area was considered as a miserable mass murder during 1968-1980. Furthermore, longitudinal deforestation made by the villagers and concessionaires led to a tragic flood in 1988 . The event was marked as one of the worst natural disasters in Thailand that led to a total logging ban nationwide in 1989. Now, two reservoirs have been built to replace the flooded areas. The spectacular mountain scenery of the two reservoirs and other national resources are now used for tourism purposes. Using dark tourism to convey these tragic messages as a symbolic reminder of human mistakes to the outside world can contribute as lessons learned to all mankind.
\end{abstract}

Keywords: Dark tourism; Tragic flood; Forest concession; Communism; Phipun

Received: 31 January 2019

Accepted: 2 March 2020

\footnotetext{
- Corresponding author. Faculty of Humanities and Social Sciences, Prince of Songkla University, Email: yusop.b@psu.ac.th
} 


\section{INTRODUCTION}

Dark tourism is considered as a phenomenon which encompasses the presentation and consumption of real and co-modified death and disaster sites (Lennon, 2009) or as the "visitation to places where tragedies or historically noteworthy death has occurred and that continue to impact our lives" (Tarlow, 2005: 48). Catastrophes or great loss of life and suffering occurs daily around the world. Dark tourism, thus, appears to be a manifestation of the present media-rich society that can enable people to learn more about tragic historical sites or trace back with fascination, deaths and disasters, as Robinson (2016: 1) opines that "It may be macabre, but dark tourism helps us learn from the worst of human history".

If we consider Thailand as a case, many places can be considered and classified as dark sites, consequently, dark tourism. For example, first, the Democracy Monument in Bangkok dedicated to protesters against the military regime in 1973 now has become 'the rally point' whenever there is a political trouble, which, in most cases, leads to death. Second, the Bridge on the River Kwai in Kanchanaburi province forms part of the so-called 'Death Railway', a rail line built by countless soldiers during WW II. Third, the 2004 Devastation Tsunami in Phuket and provinces along the coastline of Andaman Sea can also be regarded as one of the most tragic events in Thai living history. Based on these three examples, it is now clear that without past narration of events, the younger generations may not know and learn about their tragic (local) history and, sooner or later, those stories may fade over time. To preserve the miserable stories as lessons learned, dark tourism can play a remarkable role in making tragic events come alive and recognize again (Lennon, 2009). However relevant dark tourism to our contemporary generation, in Thailand, dark tourism has not been given proper recognition. The official website of the Tourism Authority of Thailand (TAT), for instance, attempts to promote the newly emerging types of tourism. Dark tourism, however, is still not included in the TAT website or in the 'The National Tourism Development Plan 20172021' (National Policy Committee for Tourism, 2017; Sharafuddin, 2015). This notation inspired this research team to account for some of the surprised and unexpected research findings in Phipun District that can be considered as dark tourism.

\section{CONTEXT}

Phipun is one of 23 districts of Nakhon Si Thammarat province in the South of Thailand. The district is located at the foot of Nakhon Si Thammarat Mountain Range (Buddharat, 2003). The mountain is not only rich in the abundance of natural resources, such as, streams, waterways, waterfalls, rainforests, and various species of wild plants and animals but also has watershed of more than 15 waterways. In Phipun District alone, four main waterways flow from Pa KhathunKapiat Valley through Ban Kathun and Ban Huaiko, then, join together to form the longest Tapi River in the South of Thailand (Buddharat, 2016; Tanavud et al., 2000).

For hundreds of years, local villagers in Phipun have utilized the waterways from Mt. Luang for multiple purposes. These waterways have periodically brought disasters and death to the area in the rainy season because they could be transformed into conduits for large amounts of water from surrounding mountains. The tragic event in November, 1988 was a case of this phenomenon. It was recorded that rushing waterways and landslides carried and buried residents of Ban Kathun 
and Ban Huaiko resulted in 230 deaths or injured and a billion baht worth of damage (Potigavin, 1988, Tanavud et al., 2000). As a sustainable prevention of the landslides and flooding, King Bhumibol (King Rama IX of Thailand) advised the Department of Irrigation to build two reservoirs (Figure 1) where Ban Kathun and Ban Huaiko (Khlong Din Daeng) were located in order to slow down rushing water, and to preserve water for agricultural purposes.

Figure 1: Klong Kathun and Khlong Din Daeng Reservoirs in Phipun District

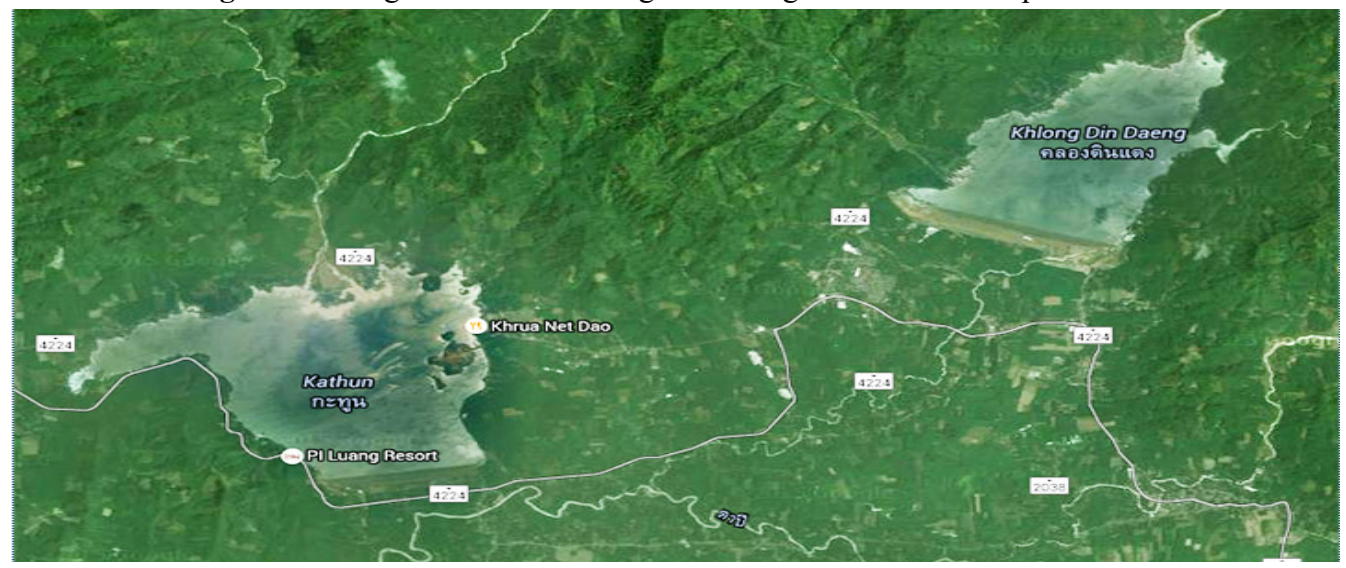

Source: http://paulsr.net/tag/khlong-din-daeng/ (2015)

While everything in Ban Huaiko area was cleared up before the Khlong Din Daeng Reservoir was flooded, people in Ban Kathun voted to keep most of the ruin (e.g. school, theaters, temple, road, etc.) flooded underwater as memorial for those who passed away in the 1988 tragic event. After the two reservoirs were flooded, the mountain scenery became pretty spectacular, particularly with a wonderful panorama of two bodies of water up in the hills.

Without providing information about the tragic events, visitors who go to these places now may only appreciate the scenic beauty of nature around the area but not the tragic lessons learned - that the Thai government used to impose a total logging ban" (Nutalaya, 1991; Thai News Agency MCOT, 2016), and the unfairness of the military regime. Based on this concern, this paper is predicated on presenting two findings which reflect some dark sides of, and opportunities for tourism business in Phipun District.

\section{METHODOLOGY}

\subsection{Data Collection Procedure}

Since this paper used tourism routes as a vehicle for collaborative economic development for the local people in Phipun District, Participatory Action Research (PAR, henceforth) was used as a fieldwork paradigm (Praphutnitisan, 2002). PAR is widely employed in social investigation for taking action to address a problem to engage in sociopolitical action (Marshall \& Rossman, 2006). The approach is concern more with the local context and the voices of the local people (bottom up 
approach) than focusing on the government's policy (top down approach). According to the above justification, the following steps proposed by Praphutnitisan (2002) were utilized in this research from June 1, 2017 to May 11, 2018.

Step 1: Researchers built rapport with local villagers in a form of "collaboration or being partners" to form "a community research team" through the selection of one villager (as co-researcher) and five other villagers (as assistant researchers). The team was a liaison between the researchers (academics) and developers in contacting key field informants.

Step 2: Researchers and community research team conducted participatory rural appraisal by holding meetings to discuss and assess issues that concern recruiting sample groups and working together.

Step 3: Researchers and the team worked together by brainstorming to prioritize problems related to research questions, drafting participatory planning for action by holding meetings to evaluate options for action plan, as well as how and when to collect data.

Step 4: Researchers and the team conducted participatory action and evaluation by implementing action plan for data collection. At this step, various types of interviews and participant observation were conducted with 24 participants including villagers, resort and restaurant owners, and entrepreneurs, following ethical guidelines. The data from all instruments were then analyzed and cross-validated. Finally, the team brought the findings and lessons learned for community check so that local villagers, community developers, researchers and fund granters can share mutual benefits from the research in the last stage (see Figure 2).

Figure 2: PAR Procedure

Procedures
$\begin{aligned} & \text { 2. Make Participatory } \\ & \text { Rural Appraisal }\end{aligned}$
$\begin{aligned} & \text { 3. Do Participatory } \\ & \text { Planning for Action } \\ & \text { 4. Operatemics/ } \\ & \text { Action and Evaluation }\end{aligned}$

Source: Praphutnitisan (2002: 80) 


\subsection{Research Instruments}

The research instruments were interview and participant observation (Creswell, 2009). The interview data were recorded in the forms of audios and videos, while participant observations were recorded as electronic field notes (typing in Microsoft word), still photographs and videos.

\subsection{Data Analysis}

The data were then analyzed using qualitative content analysis (Mayring, 2014). The analysis procedure started by transcribing all the interview data (10 informal interviews and 4 in-depth interviews) and then saved them into Microsoft words. The data from participant observations were reorganized and renumbered so that it would be easier to subsequently retrieve data extracts. After that, all the transcriptions, field notes and photographs were intensively read, reread, and checked through description, line by line and photo by photo until we were familiar with the whole dataset and confident that we would be able to generate initial codes that will address and support our research questions. Subsequently, a list of themes was made to compile emerging themes such as "abundant natural resources, paddy farmers, tin-mine workers, forest concession, non-stopraining, flood and landslides, uprooted-trees, buried alive, King Rama IX, reservoirs, the red-zone, etc. (see part of example interview protocol in Appendix 2). At this point, to enhance reliability, co-researchers were regularly involved as intra -raters. As soon as the coding was done, all the themes were re-categorized to build the main categories for each research question. Finally, all the selected themes in the main categories were brought back for community check before concluding on the final findings. In order to fit in with the aims of this paper, only the categories of themes related to communist invasion, tragic flood, reservoirs, and tourism were selected.

\section{RESULTS}

The data revealed that three main villages: Ban Huaiko, Ban Kathun and Ban Yangkhom in Phipun District were the places that could be considered as a case study of a symbolic reminder of human mistakes that should not be repeated in the future. These places are approximately 700 kilometer from Bangkok or 100 kilometer from tourist attractions in Surat Thani province.To report these findings, the villagers' real life events were described chronologically (Table 1). The report started with describing the pre-darkness period of the local villagers (before 1962) until they were invaded by the Thai communist party (1968-1980). Subsequently, the detailed description about continuous deforestation (1984-1988) was described. The incidence was then linked to the massive flood and landslide in which it has been considered as one of the worst natural disasters in Thailand (1988). Finally, the emergence of the dawn period for villagers (1999-present) under the patronage of King Rama IX and the assistance from outside organizations were described. Now, community tourism business has become a new opportunity to earn extra income by local villagers. 
Table 1: The Chronological Order of the Villagers' Real Life Events, from Dark to Dawn

\begin{tabular}{|c|c|c|c|c|}
\hline Pre-Darkness & \multicolumn{3}{|c|}{ Darkness Period } & The Dawn Period \\
\hline Before 1968 & 1968-1980 & 1984-1988 & 1988 & 1999-present \\
\hline $\begin{array}{l}\text { Villagers are living } \\
\text { as poor paddy } \\
\text { farmers, tin-mine } \\
\text { workers, fruit } \\
\text { orchard owners, and } \\
\text { rubber plantation } \\
\text { owners }\end{array}$ & $\begin{array}{l}\text { Invasion of } \\
\text { Thai } \\
\text { Communist } \\
\text { party into the } \\
\text { area (deep } \\
\text { despondency } \\
\text { and prejudice.) }\end{array}$ & $\begin{array}{l}\text { Continuous } \\
\text { deforestation: } \\
\text { - expanded } \\
\text { rubber plantation } \\
\text { - allowed 'forest } \\
\text { concession' }\end{array}$ & $\begin{array}{l}\text { Tragic flood and } \\
\text { landslide, one of } \\
\text { the worst natural } \\
\text { disasters in Thai } \\
\text { living history. }\end{array}$ & $\begin{array}{l}\text { - Outsiders' } \\
\text { contribution } \\
\text { - Two reservoirs } \\
\text { have been utilized } \\
\text { for tourism } \\
\text { purposes. } \\
\text { - Historical \& } \\
\text { natural, Cultural, } \\
\text { and Agricultural } \\
\text { tourism have been } \\
\text { operated. }\end{array}$ \\
\hline
\end{tabular}

\subsection{Pre-Darkness Period (before 1968)}

Phipun Districthas been in existence has been located at the foot of Nakhon Si Thammarat Mountain Range for more than 400 years. The mountain has abundant natural resources including streams, waterways, waterfalls, rainforests, and various species of wild plants and animals. Local villagers of Ban Huaiko, Ban Kathun and Ban Yangkhom in the past engaged in several activities to earn a living. For instance, collecting food stuff from the forest and creeks, as well as working in their farmlands and tin mines as an ex-village headman and resort owner explains:

"In the past, Phipun district used to be residential areas with farmlands for local villagers, mainly for paddy field, fruit and rubber plantation, houses and other wooden-buildings such as temples, government offices and schools" (Key informant (KI henceforth) 1). "Ban Kathun used to be a nice, quite-rich village due to its location and natural resources in the area. In the past, local people were paddy farmers and mine workers. Apart from tin-mine-tin, wolfram, and gold, rubber plantation was also another popular business for people here. Rubber was needed not only to make torches in the tin-mine but the products were also sold to traders in other areas" (KI 2).

\subsection{Dark Period: Invasion of Thai Communist party (1962-1980)}

The data indicated that due to the abundant natural forest and fertile land in Nakhon Si Thammarat Mountain Range, the Thai Communist Party chose to set a campsite in the mountain where it is now YangKhom Sub-District in Phipun District. The area is the origin of the watershed of four main waterways flow from Pa Khathun-Kapiat Valley through Ban Kathun, Ban Huaiko and Ban YangKhom then join together to form the Tapi River; the longest river in the Southern Thailand. Moreover, the data also unveiled a surprised and unexpected story about the invasion of communist party in the area during 1968-1980. 
"We were not only in deep despondency and prejudice but our district was labeled as the red zone [dangerous zone]" (KI3).

The same story was also confirmed by present-day sub-district headman and other villagers,

"Yangkhom Sub-District was claimed to be the red-zone and other areas in the district were pink-zones [caution zones]. Ban Yangkhom, where Phipun Hospital is now located used to be a Royal Thai Military Fort set up by the Thai government (Figure 3) to fight against communists while Nuea Fa Waterfall, where the National Park Office is now locatedused to be communists camp sites, paddy field, rice mill, storage rooms, wells, cottages, medical care center, acupuncture training room, etc" (KI 3 ).

Figure 3: Phipun Hospital, a Former Military Fort is Now Used as an Office for Security Guards
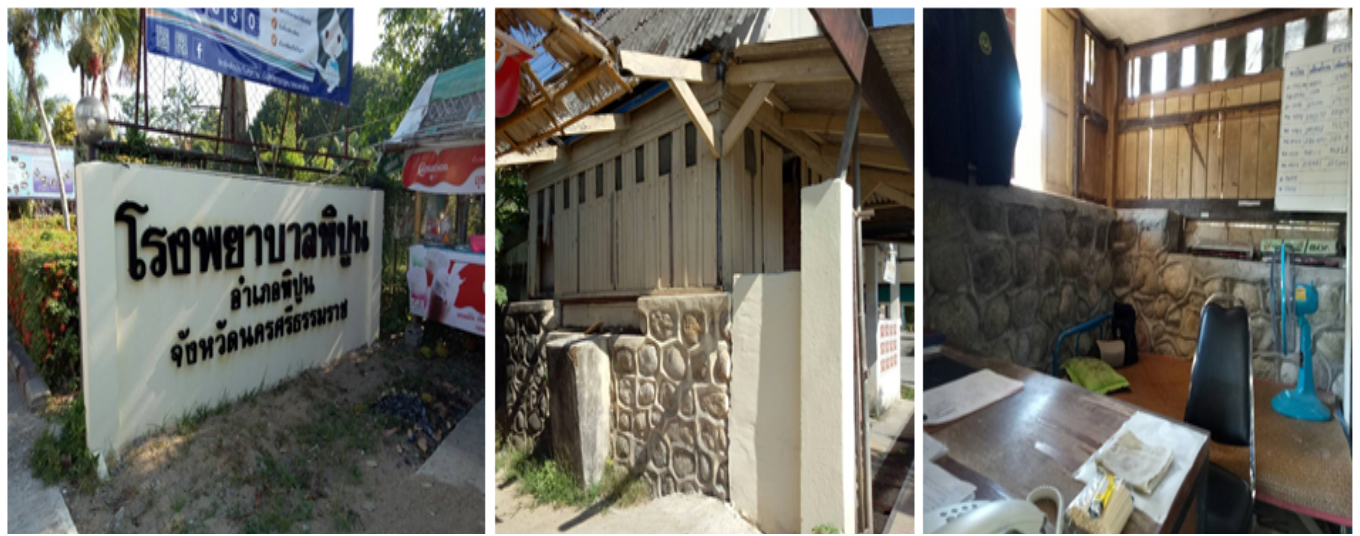

Source: Researchers' Own Photos (2017)

With regard to the communism's background in Phipun district, a key informant described that:

"The communism did not first take place in the South of Thailand. It occurred in the Northeastern region around 1962. It was persistently extended to Phipun District as the first territory in Nakhon Si Thammarat around 1968. At that time, the mountain zone in Phipun District was a prosperous area for Thai's communists. These group of people convinced local villagers to participate in the movement to anti Royal Thai government's regime and become part of the complicity situated in the deep forest" (KI 7).

The logic describing why villagers had become communist has been stated as:

"It happened due to the difference in political points of views between government officials and villagers" (KI 8).

"Any villager whose relatives took side on communists and chose to move up to the mountain, live there, would be regarded, immediately, as a communists by government 
officials. Sooner or later, these group of people would be subsequently killed by the government soldiers; not only the ones who took side but the whole family" (KI 7).

"The killing strategies used by soldiers such as "shot dead, burnt alive, put into hemp sacks then threw them into helicopter and cast off in the mountain" (KI 5; KI 6; KI 7; \& KI 8).

“...dig a pit and buried oneself...” (KI 5) or "let go but sniper" (KI 3; KI 5; \& KI 8).

Family mass-murder became the main reason why more and more people thought of contacting communist network in order to evacuate themselves and their family members to the mountain for protection. The headman and the guard explained that:

"... at that time, we should be neutral even when the situations got worse and worse. That was the most important and difficult strategy for us to learn to survive in our hard time..." (KI 3).

"We had to join both parties so that low-impact was made to neither side and, most importantly, we survive!” (KI 8).

"... more than 1,000 innocent villagers were killed in that event" (KI 3 \& KI 8).

According to the data from KI 3 and KI 8, it can be summarized that "from 1977 to 1978, the district chief officer had wiped out the communists in cooperation with the peace policy of Army Area, Region 4. The chief official of Army Area, Region 4 had imposed the policy 66/33 as the guideline used in the South of Thailand called National Army Peace. He operated in the political aspect by using the former communists who had turned themselves to be national developers. In terms of military, Army Area, Region 4 and other regions formed, as the national army began to attack and seize the Camp 508, the communist's strongest and biggest fort in the South, as well as other smaller camps. In 1982, everything regarding communism had consistently begun to disappear and vanish in the end as their leaders and other key individuals were short dead."

\subsection{Dark Period: Continuous Deforestation (1984-1988)}

Apart from the communist invasion, the destinies of the people in Phipun district were still determined by themselves and outsiders. The data revealed that the tragedy happened to the local villagers owing to their own continuous deforestation from illegally ${ }^{1}$ expanding rubber plantation into natural forest and the forest concession permitted by the Thai government as mentioned by a key informant:

"Besides mining for tin, wolfram, and gold, the rubber plantation was also another popular business for Kathun residents. Rubber was needed not only for making torches in the tinmine the products but it was also sold to traders in other areas. As a result, local villagers may illegally expand their land into the mountain zone for rubber plantations".

\footnotetext{
${ }^{1}$ The Department of Royal Forestry declared Mt. Luang as a National Park in 1974 (Gray et al., 1991). However, the Thai laws did not seem to be seriously strict at that period of time (First author's personal opinion based on empirical evidences in Thai public domain and personal experience living in rural area).
} 
Furthermore, "around 1984, the Thai government allowed 'forest concession' and a huge amount of big trees in Khao Luang Mountain Range where the Phipun District was located to be cut down for logging business. The concessionaires used modern technology such as power chain saws, tractors and rangers in their concession zones" (KI 3).

Local villagers and businessmen had an idea that:

"wood and forest was the asset which there were plenty on the mountain and could be traded easily for the money" (KI 2).

"Some villagers work for or assist concessionaires to lead and track them up to the mountain. They did not anticipate what would happen if they cut heedlessly and sold most natural forest" (KI 9).

\subsection{Dark Period: Tragic flood and Landslide (1988)}

The concession continued until November 1988 when there was continuous heavy rain for about 7-8 days and nights. The most severe ones were on the 21st - 22nd when the rain did not stop for the whole days and nights. Consequently, the soil on the mountain was saturated and could not retain the water anymore.

"The massive amount of rushing muddy water with uprooted-trees, logs, stones and sand spilled from the surrounded mountains flew down to communities and completely destroyed all 5 villages. Not only almost all houses, farmlands, schools, two cinemas, temple, and government offices were destroyed but numerous villagers, particularly at Ban Huaiko and Ban Kathun were buried alive, over 2 meters" (KI 1, KI 3, and KI 11).

The data from the group interviewed also revealed that some survived flood victims were had no food to eat and no cloth to wear. They were also injured and became homeless.

One of the key informants expressed his opinion on why the situation was too severe:

“... imagine, muddy water, soil, big logs, up-rooted trees and even a large area of farmland moved down into waterways then dumped into our community, destroyed our houses, farmland and everything in our villages? The whole farmlands looked like a dessert" (KI $10)$.

To proof the key informants' claims, the evidence from archival research is presented in figure 4. 
Figure 4: Massive Flood and Landslides in Phipun District, November 22, 1988

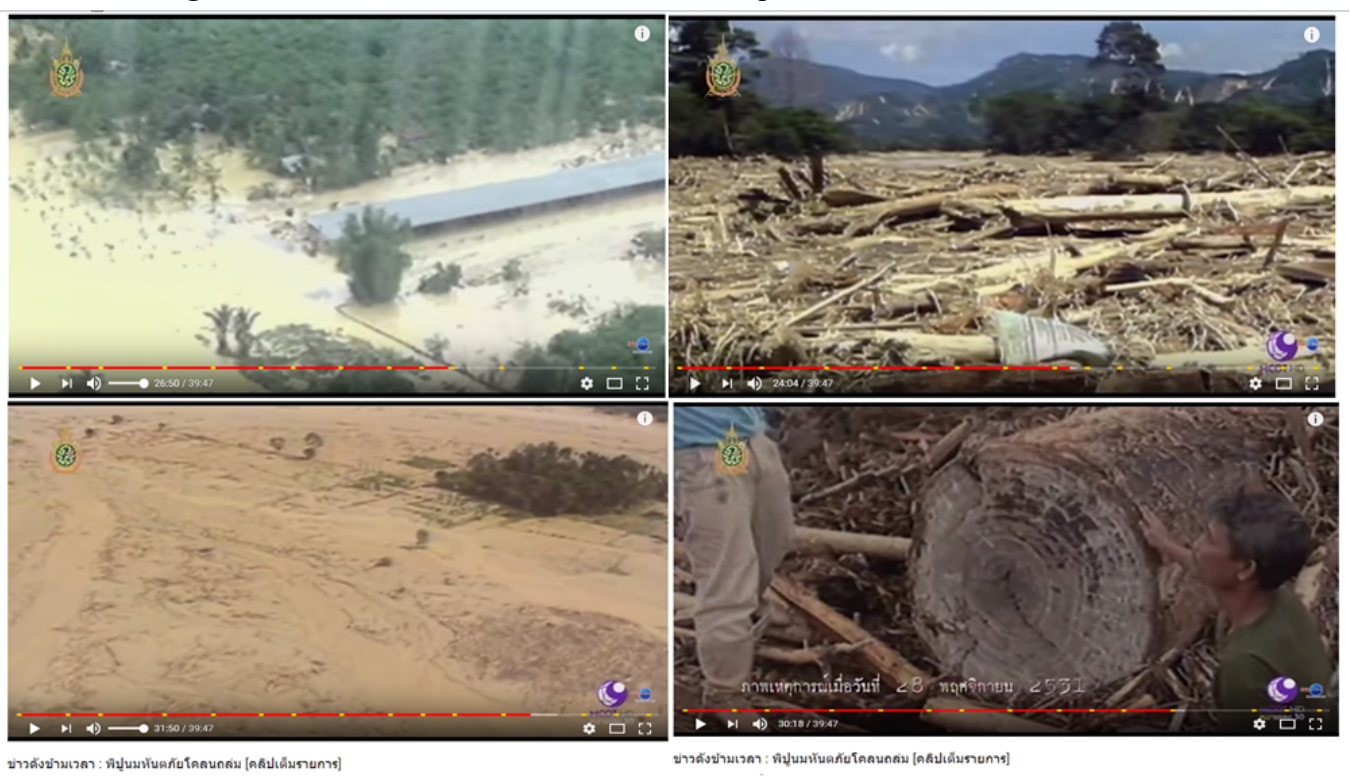

Source: I ha1 News Agency MLUI nttps://www.youtube.com/watch\% V=Hb/nnLevbm1 L, ( 2010$)$

When asked about the causes of the massive flood and landslide, a community headman and his neighbors explained that:

"we were buried alive because of the carelessness and irresponsibility of the concessionaires as well as the government officials. ... If there were some small creeks in the concession zone. Concessionaires carelessly filled them with soil and small branches of trees to make tracks for tractors and rangers. Once it rained, these tracks turned to be water blockers. It was like they built some small dams in the mountain. When it rained continuously for a week, how can the careless manmade logged dam retain the large amount of water? When one dam collapsed, the other also could not retain the water. The amount of water roll-down from dam to dam like a domino and formed a massive amount of water with log and trees flowed down into the villages" (KI 3, KI 11 and KI 12).

"The deforestation was not only done by local people but we mainly put the blame on the press" (KI 3).

Other two villagers told a similar story about the causes of the disastrous flood and landslides:

"The cause of the flooding was the continuous deforestation and irresponsibility of the concessionaires (KI10) and government officials as well” (KI 3).

\footnotetext{
${ }^{2}$ See more details about massive flood and landslides as well as the response of Thai government through this link (In Thai)
} 
"I confirmed that at least 6,000 big and huge trees were cut down. How could poor villagers with hand tools be able to do all this?" (KI 3).

This situation was confirmed by the former assistant village headman who felt uneasy and disappointed with the national bureaucratic system and capitalist system.

"...they used tractors and rangers instead of elephants. These heavy machines made the soil loose. When we have non-stop heavy rain, the huge amount of water spilled into the creeks and poured down into the villages. ...they claimed that they cut only small trees but it was not true. The flooding situation had never been severe like this before" (KI 10).

\subsection{Dawn Period: 1999-present}

\section{Outsiders' contributions to recovery from the disaster}

The data explained by KI 1; KI 3, KI 11 \& KI 12 indicated that due to the catastrophic event in the area, the effects were too severe for the local villagers to manage by themselves, therefore, government sectors and outside organizations such as The Fourth Army Area 4, Nakhon Si Thammarat Red Cross Society, World Vision Foundation of Thailand, UNICEF, and other organizations needed to provide instant assistance to them. Moreover, King Rama IX and Princess Chulabhorn also offered urgent assistance and support. The royal short-term help was launched promptly. The long-term helps also started immediately after the flood but the projects took many years to be completed.

In the case of the two reservoirs, the ex-building contractor, a former assistant village headman and the irrigation engineer explained that:

"the King had royal initiatives to Royal Irrigation Department Area 11, Nakhon Si Thammarat province to survey the flooded areas and finally made decision to construct them at Ban Kathun and Ban Huaiko. The reservoir was constructed in 1992, four years after the worst severe food and landslides, and completed in 2002. The key reasons in building the reservoirs were to slow down rushing water in rainy season, and to keep water for agricultural reasons in summer" (KI 2, KI 10 \& KI 13).

The two reservoirs from the king's projects have been considered as dawn or new lives by local villagers. With the two reservoirs, the lush mountain scenery around the two areas became spectacular views for tourists and photo hunters (see figure 5). Every year, many visitors in and outside Nakhon Si Thammarat Province visit our reservoirs. They name our places as:

"Twin lakes in Valley, Switzerland in Thailand, Twin Lakes in the Mist, or A Town of Two Reservoirs" ( KI 2; KI 3; KI 9 \& KI 10). 


\section{Emerging of Community Tourism}

The findings revealed that Phipun District is now suitable for tourism purposes. The potential tourist attractions can be classified into three main groups: (1) Historical and natural tourism which include the natural beauty of a mountain range, a national park, and the two reservoirs under the royal projects, as well as stories of tragic history concealed behind the scenic view (e.g. living difficulties of villagers as poor paddy farmers, tin-mine workers, survivors from communist invasion, and victims of devastating floods and landslides); (2) Cultural tourism that comprises old temples dated back to the Kingdom of Ayutthaya, as well as the King Rama IX's period, The Ceramic and Pottery Center under the royal patronage of HRH Princess Chulabhorn; and (3) Agricultural tourism which is consisted of Fruit orchards, the Agricultural Technology Center, TieDyed Cottage Industry, Goat Farm, Hat Making House, and Model Farm implementing King Bhumibol's philosophy (participant observations, June 9, October 21; November 16, 2017 and March 17, 2018).

Figure 5: Spectacular Views Around Klong Kathun Reservoir

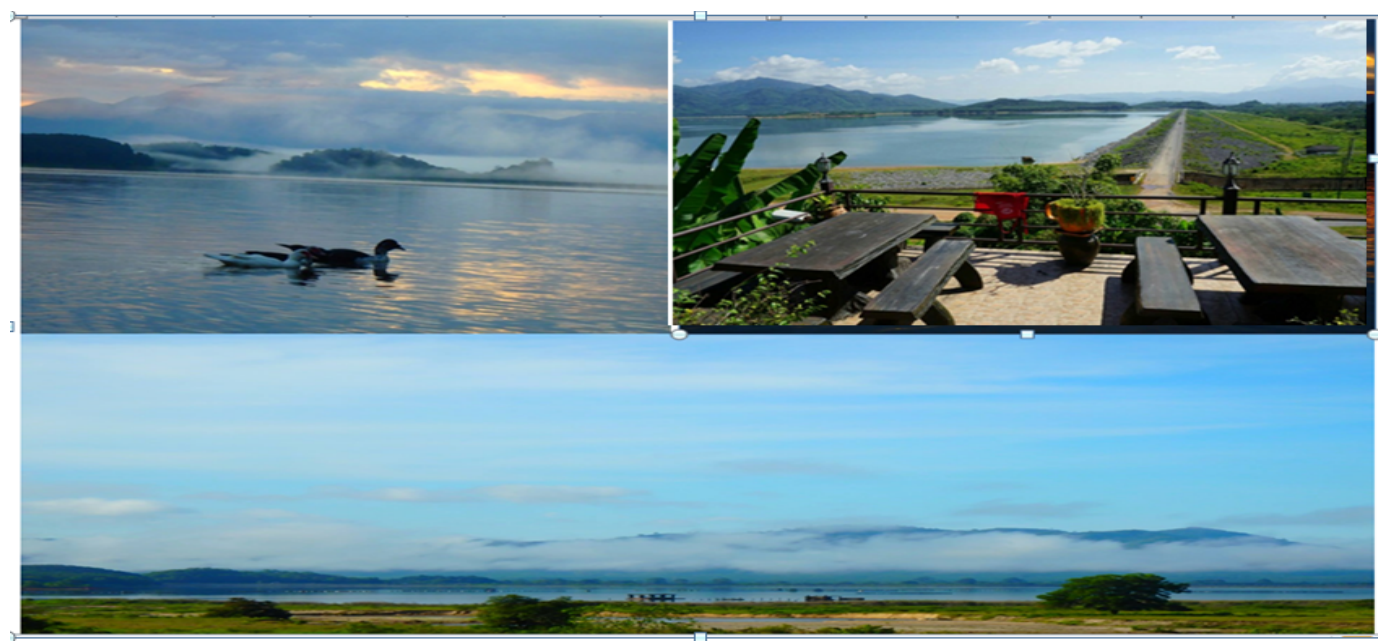

Source: Researchers' Own Photos (2017)

\section{Accessibility and Amenity}

Apart from the tragic stories and its natural beauty, the areas are easily accessible. Moreover, many resorts and restaurants with on-site food and drink are available all year round (participant observation). When asking about how to get to the place, the answers are:

"visitors can fly to Nakhon Si Thammarat Airport or Surat Thani International Airport. Then, from the city of Nakhon Si Thammarat, they can take a bus, a van or a Song Thaeo ${ }^{3}$ which will take about an hour. From the city of Surat Thani, visitors can also take a van

\footnotetext{
${ }^{3}$ Song Thaeo is a local public transportation. It is a pick-up truck with a canopy on the back and the passengers sit in the back.
} 
or catch a train from Surat Thani Train Station and get off at Chandi Station in Nakhon Si Thammarat Province, and take Song Thaeo to Phipun. The whole trip may take about 2 hours" (KI 12).

The recommended resorts, according to information from the owners and researchers' participant observations, are Ban Chomdao Resort, Phi Luang Resort, Chop Rimnam Resort and Baan RomLomYen. The first three resorts are located along the side of Klong Kathun Reservoir, while Baan RomLomYen is on the way from Khlong DinDaeng Reservoir to Klong Kathun Reservoir, about 10 kilometer from each other. Room rates of all resorts start from 500 to 1,400 Thai Baht. Every unit is fitted with a private bathroom, shower and western style toilet. Some units include a terrace and/ or balcony with garden of local plants, fruit orchards and panoramic water and mountain views of Kathun Reservoir. There are also free Wifi and private parking lots available. Visitors can also enjoy Thai or Western food and drinks for all meals at each on-site restaurant. The recommended restaurants can be Chop Rimnam, Phi Luang, Im Lamai, Baan RomLomYen (an English speaking local guide is available), and Ran PaThueang. These restaurants are located along the main road from Klong DinDaeng to Klong Kathun. At Chop Rimnam Restaurant and Phi Luang Restaurant, various kinds of Thai food and drink are served. At Im Lamai Restaurant and Baan RomLomYen both Thai and Western foods and drinks are served and the owners are able to communicate in English, particularly at Baan RomLomYen. Any visitors who love to try a real taste of local Thai food, Ran PaThueang is strongly recommended because various kinds of rare local vegetables, fish and meat are used in cooking. Another uniqueness of Ran PaThueang is "selfserviced" style of serving.

Klong Kathun Reservoir is not only the best place to take photo at any time of the day, but Klong DinDeang Reservoir is also the best for photo taking lovers. Klong DinDeang Reservoir has many attractions such as the beautiful scenery around the reservoir, trail for walking, jogging and cycling, space for family picnic, vacation, and excursion. If it rains, tourists can also enjoy the wide sea of mist which is best for taking photos. Moreover, there are local rare plants along the ridge. Tourists can use any type of transportations to be at Klong DinDaeng Reservoir. Furthermore, the attractive locations have some facilities to support tourists, such as, Pracha Ruamchai Community Center which can be used to relax, talk, and provides tables, chairs, free Wifi and space suitable for organizing parties and meetings by the reservoir.

Nuea Fa Waterfall tends to be interesting for visitors because it is located in Mt. Luang National Park. Accessibility is also convenient. Visitors can use all types of transportation to get there-about 10 kilometers from the main road. The water from the waterfall has been certified by the Pollution Control Department as the cleanest natural water resource. The waterfall is also part of the origins of Tapi River, the longest river in the Southern Thailand. In addition, Nuea Fa Waterfall has a vast space for outdoor activities and photo shooting. Inside the area is the Mt. Luang National Park Office, in charge of taking care and organizing activities for tourists, in addition to controlling water pollution activities.

\section{Visitors}

The data suggested that visitors to Phipun District are from all walks of life across different ages. The places are more crowded during long weekend, national holiday and religious holiday. Mostly, 
visitors are those who come with friends to visit their families, relatives and friends in the home town. Some come to enjoy nature, celebrate their special occasions, and find new places to enjoy different taste of food, beauty, and so on.

“... Most of our visitors are teenagers who come to relax and enjoy our beautiful nature at our reservoirs and waterfall. ..." (KI 12).

"Most are our relatives who work in other provinces. These groups bring their friends to visit the places. ... Some government officers from nearby provinces come and stay overnight for special occasions. ... Teachers and students often come to organize Boy Scout and Girl Guide activities and camping" (KI 9).

"We have customers in our restaurant every day. ... Those who stay overnight are government officers, sales representatives and tourists" (KI 18).

From the data provided, Phipun District can be described as a potential tourism destination when assessed based on numbers, types and time spent of visitors.

\section{DISCUSSION}

The salient unexpected findings are the cases of details about the nearly 13 years of invasion of communism in Phipun District as well as the tragic flood and landslides in Ban Kathun and Ban Huaiko in 1988. These two phenomena are key points to discuss here.

While the cleanest natural water and the beauty of Nuea Fa Waterfall attract more and more people to visit, what is behind the beautiful scenery is a miserable story of communist's invasion, "....More than 1,000 innocent villagers were killed..." Furthermore, the lessons learned from killing innocent villagers could be defined as a Phipun's nightmare and should be considered as a case study not to be repeated. The clarification of this claim was that when considering the causes of miserable story in Phipun, it was, in fact, originated from the Thai political conflicts at national and international levels during 1965-1982 (see details in Bergin, 2016) but the victims were some innocent villagers. This type of tragic storytelling, interestingly, can be used for "tourism reasons" (Wisutthilak, 2013) as a popular attraction of Phu Hin Rongkla National Park in Phetchabun Province. The place turns a major battlefield in the war against communism (MThai.com, 2013).

Since the area was a tropical rainforest with abundant natural resources, wildlife, and rare plant species, business enterprises were attracted to exploit the area. Consequently, a number of concessions were issued to some private entities to utilize the area neglecting the fact that such provisions could later create an irreversible deforestation, foothill construction, and slope rubber plantation. Ignoring the long-term effect for short-term benefits, it was further evident that, according to the data from Ban Kathun, the "local people expanded their land into national park for rubber plantations" and "... when there were non-stop-raining for seven days, massive landslides occurred..." These data tally with Tanavud et al. (2000) who proposed that the catastrophic landslides in Phipun District caused by the confluence of natural conditions comprised of granite mountains, steep slopes, and intense rainfall for one reason or another was human encroachment and the conversion of natural forest to shallow-rooted rubber plantation. What happened was defined as a "Phipun's nightmare" leaving the district with permanent miseries. On the day of the event, the victims lived their lives as usual and they failed to perceive the eminent 
danger. Some survived victims described seeing a number of shaped logs flowing along the flood and the images of the mud and logs burying countless bodies were unforgettable. The flood and landslide was marked as one of the worst natural disasters in Thailand. Everything they saw was destroyed in a split second. The message and empirical evidence imparted strong information to central government. "The royal Thai government officially imposed a total logging ban in natural forests in January 1989” (Nutalaya, 1991; Thai News Agency MCOT, 2016), only two months after the flood.

All in all, the government and local people of both Phipun District and in Phetchabun Province learned the hard way through tremendous suffering and losses. It is thereforean aspiration for the area to be revitalized and formed into a new beauty to subside the past bitterness. If Phipun District is to be considered as a case study not to be repeated, local residents should be strong enough to protect their natural resources. This history was about to be repeated in Chiang Mai province as the judicial housing construction recently commenced in Doi Suthep (Online reporter, Bangkok Post Online, April 30, 2018). What happened earlier to Phipun was caused by negligence and irresponsibility of the people and government in the past. What is happening to Chiang Mai is seemingly indifferent as the constructor in Doi Suthep clears up a densely forested area and starts the foothill construction. Phipun's nightmare must no longer be repeated and what the Tourism Authority of Thailand (TAT), Designated Areas for Sustainable Tourism Administration (DASTA), and other authoritative agencies can do within their juristic scopes are to put a preventive effort to resurrect these unfortunate destinations and promote them in a form of dark tourism; turning the tragic past to current beauty and promoting the areas as a symbolic reminder of human mistakes.

\section{CONCLUSION}

Tourism contributes substantially to the Thai economy and national GDP. Where there is a concentration of tourist, there is a substantial economic growth. However, for dark tourism, it is still rarely recognized in Thailand although there are many places that can be classified into this type of tourism - Phipun District can be one of them. This study provided a storytelling of the two tales of tragedy that created a remarkable influence to a nationwide action against deforestation the benefactions of King Rama IX's project. After the data were collected from the key informants including 24 villagers, 5 resort and restaurant owners, and 5 entrepreneurs through interview and participant observation, a qualitative content analysis was applied to the data. It revealed that the history of Khlong DinDaeng Reservoir, Klong Kathun Reservoir, and Nuea Fa Waterfall could be considered as the tourism resources for dark tourism. Khlong DinDaeng and Klong Kathun Reservoirs were built due to problems of deforestation, flood and landslides. Furthermore, the beauty of nature and the reputation of the cleanest natural water in Thailand at Nuea Fa Waterfall conceal the tragic story of the communist invasion at Yangkhom sub-district and used Nuea Fa Waterfall as one of their large camp sites in the South of Thailand.

\section{ACKNOWLEDGEMENT}

This paper is part of a larger project entitled- Tourism Routes as a Vehicle for Collaborative Economic Development of Phipun District, Nakhon Si Thammarat Province, sponsored by Thailand Research Fund (TRF) and Nakhon Si Thammarat Rajabhat University (NSTRU), 20172018. 


\section{REFERENCES}

Bergin, B. (2016). Defeating an Insurgency-The Thai effort against the communist party of Thailand, 1965-ca. 1982. Studies in Intelligence, 60(2), 25-36.

Buddharat, C. (2003). The Management of Eco-Tourism in Ban Kathun Village, Phipun District. Office of Higher Education Commission, Bangkok, (in Thai), pp.108.

Buddharat, C. (2016). An Ethnographic Study of Role of Languages in Ban Khiriwong, Thailand. (Doctoral Dissertation, King Mongkut's University of Technology Thonburi, Bangkok, Thailand). Retrieved from file://C:/Users/Adminstrator/Downloads/LNG411.pdf

Creswell, J. W. (2009). Research Design: Qualitative, Quantitative, and Mixed Methods Approach ( $3^{\text {rd }}$ ed.), Thousand Oaks. SAGE.

Euromonitor blog. (2016). Top City Destinations Ranking of 100 of the world's leading cities. Retrieved from https://blog.euromonitor.com/2016/01/top-100-city-destinationsranking-2016.html

Gray, D., Piprell, C., and Graham, M. (1991). National Parks of Thailand. Industrial Finance Corporation of Thailand Project, Communication Resources (Thailand), Bangkok.

Lennon, J. and Foley, M. (2009). Dark tourism- The attraction of death and disaster. London: Cassel.

MThai.com. (2013). Phu Hin Rongkla Historical Battlefield and Amazing Natural Beauty. Retrieved from https://travel.mthai.com/region/central/66472.html

Marshall, C. and Rossman, G. B. (2006). Designing Qualitative Research (4 $4^{\text {th }}$ ed.). Thousand Oaks, CA: Sage.

Mayring, P. (2014). Qualitative content analysis: theoretical foundation, basic procedures and software solution. Klagenfurt.

National Policy Committee for Tourism. (2017). The National Tourism Development Plan 20172021, Department of Tourism, Ministry of Tourism and Sport, Bangkok.

Nutalaya, P. (1991). Recent slope disaster due to heavy rainfall in Southern Thailand and Their mitigative measures. Proceedings of the Second Seminar on Natural Resources Conservation and Environment of Thailand (pp. 370-395). Bangkok, Thailand.

Online reporter. (2018). Wissanu rules out Sect 44 for Doi Suthep houses. Bangkok Post Online, April 30, 2018. Retrieved from http:// www.bangkokpost.com/thailand/general/1455390 wissanu-rules-out-sect-44-for-doi-suthep-houses

Paulsr.net. (2015). Klong Kathun and Khlong Din Daeng Reservoirs in Phipun District, Retrieved from http://paulsr.net/tag/khlong-din-daeng/

Potigavin, N. (1988). The 1988 Landslide in Southern of Thailand. Department of Land development, Ministry of Agriculture, Thailand.

Praphutnitisan, S. (2002). Participatory Action Research. Chiang Mai University Press, Faculty of Social Sciences, Chiang Mai University.

Robinson. (2016). Dark Tourism. Retrieved from https://theconversation.com/it-may-be-macabrebut-dark-tourism-helps-us-learn-from-the-worst-of-human-history-60966

Sharafuddin, M.A. (2015). Type of Tourism in Thailand. e-Review of Tourism Research (eRTR), 12 (3-4). Retrieved from http://ertr.tamu.edu

Tarlow, P. (2005) Dark tourism: The appealing “dark” side of tourism and more. In M. Novelli (Ed.), Niche Tourism: Contemporary Issues. Trends and Cases. (pp. 47-57). Oxford: Elsevier. 
Thai News Agency MCOT. (2016). "khaodang kham wela : phipun mahanta phai khlon thalom: ข่าวดังข้ามเวลา: พิปูนมหันตภร์ โคลนถล่ม. Retrieved from http:// www.youtube.com/watch? $\mathrm{v}=\mathrm{hB} 7 \mathrm{NH} 2 \mathrm{eVBmI}$

Wisutthilak, S., Saiphan, P., Tephalakun, O., \& Sindecharak, T. (2013). Creative Tourism. Designated Areas for Sustainable Tourism Administration (Public Organization) in collaboration with the Faculty of Sociology and Anthropology Thammasat University, Bangkok.

\section{APPENDICES}

\section{Appendix 1: Key informants (KIs) and their interview dates}

KI 1, former village headman, informal interview, June 30, October 21, 2017.

KI 2, owner of Chop Rimnam Resort and Restaurant (ex-building contractor), in-depth interview, October 21; November 16, 2017

KI 3, Village headman, Village No. 5, various types of Interview, June 9, 30; October 6, 9, 21; November 16, March 17, 2018).

KI 4, Abbot at Boranaram Temple, interview, October 21, 2018

KI 5, Yangkhom sub-district headman, Interview, October 21, 2018

KI 6, a truck driver at Yangkhom Temple, group interview, October 21, 2017

KI 7, a villager at Phiphun Hospital, group interview, November 16, 2017

KI 8, security guards at Phiphun Hospital, March 17, 2018

KI 9, resort owner, interview, July1, November 16, 2017

KI 10, former assistant village headman, Interview, June 9, 2017

KI 11, a villager in Ban Huaiko, group interview, October 9, 2017

KI 12, assistant village headman, Interview, June 9, 30, 2017

KI 13, Irrigation engineer, Klong Kathun and Klong Dindaeng Reservoirs, interview, June 30, 2017)

KI 14, owner of Ban Chomdao Resort, interview, June 30, 2017

KI 15, Phi Luang Resort owner, interview, March 17, 2018

KI 16, Daughter of Chop Rimnam Resort owner, interview, October 16, 2017

KI 17, Baan RomLomYen, owner, interview, March 17, 2018

KI 18 Im Lamai Restaurant owner, interview, interview, October 16, 2017

KI19, Ran PaThueang Food stall owner, interview, June, 30, 2017

KI 20 Tie-Dyed Cottage Industry, interview, June 30, 2017

KI 21 Goat Farm owner, interview, March 17, 2018

KI 22 Hat Making House,

KI 23 Model Farm implementing King Bhumibol's philosophy

KI 24 the Agricultural Technology Center 


\section{Appendix 2: Example of Interview Protocol}

Interviewers: 1. Chamaiporn/ 2. Mano (Researchers)

Key informant: (Name KI 10), former assistant village headman, Village Date. 12, October, 2017 Leading....

Q: Why does the community need two reservoirs?

A: In the past this area was farmland. Villagers built houses, temple and school here. ....over there was cattle range and pasturage. Villagers fed grazing animals such as cows, oxen, buffalos and horses for work $\rightarrow$ physical labor. Our school, Ban Huaiko was ranked number 1 in Phipun District. It was a big and nice school with a lot of trees and field for kids to run around. There were two small rivers by the school, the Huaiko Nuea. In 1984, the government allowed forest concession. The concessionaires cut to many big trees. They used tractors and rangers, power chain saws. Until, on 22 November, I remembered it was Loy Kratong Day, it rained like non-stop, whole days and nights. It is said by the academics that the soil on the mountain was saturated and could not retain the water anymore. The muddy water, tree, uprooted-trees, logs, stones and sand spilled from the surrounded mountains flew down to communities. My family was also the victims. 5 villages schools, temple were destroyed. At Ban Huaiko the sand buried our houses and this land over 2 meters.

Q: What were the causes of the severe flood?

A: Yes...it rained nearly 7-8 days, non-stop but that was one of the causes, but I didn't think it was a big issue. The real cause was careless deforestation. I prosecuted two (NAME), sawmills in case that they cut the tress outside their concessionaire zones. I won. Many workers working for sawmill and for the concession company were in jail. I was helped by some police to save my life. I was about to be killed many times because I also went to the mountain to see how they cut the trees. They made trails very carelessly. They just covered the creeks with soil and small branched. Can you imagine, it was like making many small dams to block water. So when it rained for many days how these small dams could retain the water? Only the villagers, who expanding the farmland, could not make things to be that severe.

Q: Could you explain the disaster and its aftermath?

A: The massive flood and landslides destroyed 6 villages, village number 2, 3, 5, 8, 9, and 10 . Village number 2, 3, and 9 were not so serious, only 10 household and farmlands were completely wiped out by the flood. But village number 5, 8, and 10 were severe. More than 200 villagers were swept away by the tragic flood and landslides but only about 70 bodies were found.... Even two storey building were swept away, don't ask about one storey house, domestic animals, grazing animals... we have nothing left.

Q: How about the assistance?

A: At that time, the local people had to take care of themselves for a couple days before the outside organizations and government officials came to assist us with dry foods, water and first-aids, but not all the victim. Then the medical team and emergency mobile health unit also came to take care of injured people but it did not cover all household. For the houses with the severe flooding, they cannot be accessed. Even the houses of the informants themselves were completely damaged. The flood victims had to survive without any food for 2 days until they made decision to live by the 
dead pigs and cows from the flooding. The only way they could do was to grill because no cooking equipment left for cooking proper meals. The victims had to be together under the tree for days with only one cloth until they were donated. After that the outside organization came to help us built zinc roof houses and some tile roof houses.

Q: How and how long did it take to renovate the community?

A: You couldn't believe that the event was too severe for local villagers to manage by ourselves. We had nothing left to rebuild our houses. The government sectors and outside organizations such as The Fourth Army Area 4, Nakhon Si Thammarat Red Cross Society, World Vision Foundation of Thailand, UNICEF, and other organizations came to help. The most impressive was King Rama IX and Princess Chulabhorn. The King supported in the form of emergency, short-term and longterm helps. The royal short-term help was launched promptly. The long-term helps also started immediately after the flood but the projects had many years to be completed.

Q: How long did it take to build reservoirs?

A: About 10 years, from 1992 to 2002. 